\title{
A NEW GREEK INSCRIPTION DISCOVERED AT HISTRIA
}

\author{
Adela Bâltâc, Valentin Bottez
}

\section{O NOUA INSCRIPTIIE GRECEASCĂ DESCOPERITĂ LA HISTRIA}

Articolul de față prezintă o inscripție descoperită în campania anului 2007, în Sectorul Extra muros, Poarta Mare - Turnu Mare. Piesa, descoperită în poziție secundară (refolosită ca material de construcție), păstrează patru rânduri (fragmentare) ale unei inscripții în limba greacă. Din inscripție se disting clar cuvintele Agaton A... şi çortë. Personajul amintit mai este cunoscut dintr-o altă inscripție histriană. Cuvântul cortë are sensul de sărbătoare religioasă (mai apare la Histria în decretul dat în onoarea preotesei Aba a lui Hekataios) şi pare să înlocuiască termenul pangúreiß folosit în perioada elenistică târzie. Inscripția se datează în a doua jumătate a sec. II - începutul sec. III p.Chr. şi, deşi fragmentară, aduce informații interesante referitoare la viața religioasă histriană în plină epocă imperială.

Cuvinte cheie: Histria, sector Poarta Mare-Turnul Mare, inscripție, çortë- sărbătoare religioasă.

Keywords: Histria, Main Gate-Main Tower sector, inscription, cortë - religious feast.

The inscription ${ }^{1}$ we are referring to in this paper was discovered in 2007 in the Extra muros, Poarta Mare - Turnu Mare (Main Gate-Main Tower) sector ${ }^{2}$ at Histria.

\footnotetext{
${ }^{1}$ We would like to take the opportunity to thank Prof. Alexandru Suceveanu, director of excavations on the archaeological site of Histria and Dr. Paul Damian, director of excavations on the above-mentioned sector, for the permission to publish this inscription.

${ }^{2}$ Archaeological investigations in this sector started in 2000, with a general aim of obtaining new information on the Roman dwellings at Histria during the Principate, and if possible on the Greek dwellings during the Hellenistic period; the specific aim is to set to value (museum wise) an important segment of Histria's history - the early Roman period. Archaeological research in 2000-2007 offered important stratigraphical data for that specific sector and led to the discovery of several buildings and other type of complexes that can be dated to a time span ranging from the Hellenistic period to the last early Roman level (level I C -last quarter of the $2^{\text {nd }}$ century - middle of the $3^{\text {rd }}$ century A.D.); up to the present moment we have no conclusive clues for dating any of the complexes to the period subsequent to the construction of the late Roman defense wall (level II A - starting from the second half of the $3^{\text {rd }}$ century). For the preliminary results in this sector see Damian, Bâltâc 2006, with subsequent supplements in CCA 2006, 195197; CCA 2007, 198-200; CCA 2008, 165-166.
}

It was discovered in a secondary position, in a layer of debris from one of the archaeological complexes ${ }^{3}$ identified south of Tower F. The archaeological investigations here are at their beginning, therefore we cannot establish with certitude the function of the complexes identified this far. Even so, the large quantity of pottery shards (especially amphorae and provisions pots), as well as the roof tiles discovered there could indicate the existence of a workshop in that specific area ${ }^{4}$.

The inscription was discovered in cassette $\mathrm{H} 1^{5}$, square b2 (at a depth of -0.40 $\mathrm{m}$ ) in a layer of debris (pl. 1/1). The fragmentary stone was reused as a

\footnotetext{
${ }^{3}$ If two of the building complexes in this sector can be related to the Hellenistic street (street b), other dwelling complexes located south of Tower $\mathrm{F}$ seem to be related to street $\mathbf{e}$ of the Histrian street system. See Damian, Bâltâc 2006 and supplements in CCA 2008, 165-166 and endnote 1 . For the names of Histrian streets see Suceveanu 1982, 13-39; 75-92.

${ }^{4}$ CCA 2008, 165-166.

${ }^{5}$ For the research methodology and excavation tags see Damian, Bâltâc 2006, 136 and fig. 2.
} 
construction block, as it still bears traces of mortar (relatively fine, composed of lime, sand and small stones) on the flat surfaces and sides, and burnt clay (left over from the contact with bricks - only on face a).

The text is inscribed on a rectangular block of white marble (max. length $=19.5 \mathrm{~cm}$, height $=15.5 \mathrm{~cm}$, thickness $=5.3 \mathrm{~cm}$ ), broken in the upper left side of the inscription and on the entire right side of the text. For an easier description we will call face $\mathbf{a}$ the uninscribed side and face $\mathbf{b}$ the inscribed one ${ }^{6}$.

Face a (pl. 1/2 and 4): very smooth and well worked. On one of the long sides there is a badly preserved edge (3cm wide) with a double profile. The first step of the profile is almost invisible, while the second is $0.3 \mathrm{~cm}$ high. On the face's entire surface there are small chips made with a sharp object probably to obtain adherence with the mortar. There are also a few traces of burnt clay, left over from the moment the object was used as construction material.

Face b (pl. 1/2 and 4): on the entire surface there are chisel marks, which indicate that the object was reused as an inscription later, and that face a was visible in the initial moment of use. On face $\mathbf{b}$ parallel lines were incised (set $2 \mathrm{~cm}$ apart, visible on lines 2, 3 and 4), between which the letters were later inscribed. The letters, of medium quality, are $0.1 \mathrm{~cm}$ deep and $2 \mathrm{~cm}$ high. Alpha with a broken cross bar and tau with a barrette at the middle of the vertical hasta. The text's lines were inscribed $1 \mathrm{~cm}$ apart. Date: second half of the $2^{\text {nd }}$ century - beginning of the $3^{\text {rd }}$ century A.D. The text ${ }^{7}$ :

\section{$\mathrm{A} \Gamma \mathrm{A} \Theta \Omega \mathrm{NA}$}

\section{ET}

ЕОРТН $\Lambda$

E

\footnotetext{
${ }^{6}$ The inscription was drawn by Ms. Simona Movilă, and the photographs taken by Mr. George Nica.

${ }^{7}$ We take the opportunity to also thank Miss Alexandra Lițu for her useful suggestions.
}

Unfortunately we could find no analogy for the text's format. The inter-lines space is of $1 \mathrm{~cm}$ and the space between the stone's margins and the first and last lines respectively is larger; therefore the inscription must have contained only the four preserved lines. As the lines were centered, the stone could not have been shorter than $31 \mathrm{~cm}$, and the first line could have contained at least another 5 letters. But taking into account the quality of the writing and the narrowness of the stone, we consider that the inscription could not have been much longer - lines 2 and 4 were may have been formed of 2 short words or a longer one.

Line 1 starts with the name Agathon, followed by the first bar of an alpha, probably the patronymic. The name Agathon is rarely used in the area of Scythia Minor once at Tomis (Agathon, son of Thallos ISM II, 125; $2^{\text {nd }}$ century A.D.) and once at Histria (ISM I, 225) ${ }^{8}$. In the case of the latter, Agathon's patronymic also starts with an alpha, the date of the inscription $\left(2^{\text {nd }}-3^{\text {rd }}\right.$ centuries A.D.) is approximately the same with that of the inscription presented in this paper, and the name is part of an album, probably that of a religious association (see further on the meaning of the word cortë). These elements allow us to suppose the identity of the two Histrians named Agathon.

In line 2 there is an epsilon and a fragmentary tau. It is hard to establish to what word these letters belong. It could have been the noun Étoß, which would be in connection with Agathon's age, or the adjective rmtësioß, which could refer to the yearly character of the feast mentioned in line 3.

Line 3 starts with the noun cortë, followed by a fragmentary lambda. The word ६ortë means religious feast, but with a larger nuance ${ }^{9}$. The term is used in many literary texts, from the Odyssey to the Christian authors, and in

\footnotetext{
${ }^{8}$ LGPN IV, 4, nos. 33 and 34.

${ }^{9}$ Popescu 1960, 293: cortë has a meaning similar (yet larger) to sunagwgë and súnodoß, which are always to be connected with sacrifices - qusíai.
} 
a large number of inscriptions from the Greek world. It appears only once in Scythia Minor, in an inscription from Histria, the decree in honor of priestess Aba, daughter of Hekataios (ISM I, 57). In this document the term is used twice, once in connection to the feasts, sacrifices and prayers sponsored and presided by $A b a$ at the beginning of each month (line 35), and the second time in connection with the feasts during which the priestess had to be crowned for her merits (line 50). In the Histrian epigraphy the term we come across for religious feast is pangúreiß, used in the late Hellenistic period (ISM I, 54). The use of the new term cortë (but not only) starting with the $2^{\text {nd }}$ century A.D. permitted E. Popescu to notice at the level of the epigraphic vocabulary the socio-economic and political changes which Histria had undergone beginning with the Roman rule and especially with the reforms implemented by Emperors Trajan and Hadrian ${ }^{10}$.
All the terms we referred to are used in the plural form. As cortë is used in the singular form, we can suppose that the lambda that follows is the first letter of the feast's name. At Histria are attested the Tharghelia (ISM I, 25 and 65), the Hermaia (ISM I, 59), the Mouseia (ISM I, 1) and the Taurea (ISM I, 60) in the Hellenistic period ${ }^{11}$, as well as a feast for Herakles (ISM I, 57) and the Rosalia (ISM I, 193) in the Roman period. As none of these feasts have names that start with lambda, we can suppose that our inscription mentions a feast unknown until now.

In line 4 only a fragmentary epsilon is preserved.

Despite the small dimensions and its state of preservation, the present inscription provides interesting new information concerning Histrian names and the rich religious life of the city in the imperial period, when focus changed from the traditional pantheon to the relation with the Roman power.

\footnotetext{
${ }^{10}$ Popescu 1960, 279.
}

\footnotetext{
${ }^{11}$ For further information on the religious feasts at Histria see Avram 2001, 577.
} 


\section{ABBREVIATIONS}

CCA - Cronica cercetărilor arheologice din România, MCC/CIMEC (the year mentioned is the year of publication).

Dacia — Dacia. Revue d'archéologie et d'histoire ancienne, Nouvelle Série (1957), Bucureşti.

SCIVA - Studii şi cercetări de Istorie veche (şi arheologie), Bucureşti.

\section{BIBLIOGRAPHY}

Avram 2001 - Al. Avram, Coloniile greceşti din Dobrogea. În: M. Petrescu-Dâmbovița, Al. Vulpe (ed.). Tratatul de istorie a românilor. I. Moştenirea timpurilor îndepărtate. Bucureşti: Ed. Enciclopedică, 2001, 571-583.

Damian, Bâltâc 2006 - P. Damian, A. Bâltâc, Histria. Sectorul extra-muros, Poarta Mare-Turnul Mare (2000-2004). SCIVA, 54-56, 131-147.

ISM I - D. M. Pippidi, Inscriptiones Scythiae Minoris Graecae et Latinae, I. Inscriptiones Histriae et viciniae. Bucureşti: Ed. Academiei R.S.R., 1983.

ISM II - I. Stoian, Inscriptiones Scythiae Minoris Graecae et Latinae. II, Tomis et territorium. Bucureşti: Ed. Academiei R.S.R., 1987.

LGPN IV - P. M. Fraser, E. Matthews et al. A Lexicon of Greek Personal Names. Volume IV. Macedonia, Thracia and Northern Regions of the Black Sea, Oxford: Clarendon Press, 2005.

Popescu 1960 - E. Popescu, The Histrian decree for Aba ( $2^{\text {nd }}$ century of our era), Dacia, N.S., 4, 273-296. Suceveanu 1982 - Al. Suceveanu, Histria VI. Les thermes romaines, Bucarest: Ed. Academiei R.S.R., 1982.

\section{LIST OF ILLUSTRATION}

Pl. 1 - 1. Histria, Sector Extra muros, Poarta Mare-Turnu Mare, caseta H; 2-3 inscriptie - foto; 4. inscriptie - desen.

\section{AUTORI}

\section{Adela Bâltâc}

Muzeul Național de Istorie a României

adelabaltac@yahoo.com

\section{Valentin Bottez}

Universitatea Bucureşti, Facultatea de Istorie Muzeul Naţional de Istorie a României valentin_bottez@yahoo.com 